\title{
Local Shareholders, Corporate Community Responsibility, and Shareholder Value
}

\begin{abstract}
This paper shows that local shareholders lead firms to engage in corporate social responsibility activities locally - corporate community responsibility (CCR). Motivated by the stakeholder theory, we find that mutual funds investing in local firms tend to increase CCR, remarkably in consumer oriented industry. Our identification strategy suggests a causal effect of local shareholders on CCR. Local shareholders and their firms employ CCR as business strategy and benefit themselves financially. Our results indicate that CCR tends to increase firm performance measured with Tobin's Q and operating cash flows, especially in the consumer-oriented industries where customer relations are critical. In addition, local shareholders (i.e. local funds) of higher CCR firms enjoy greater fund flows.
\end{abstract}

Keywords: Local Shareholders, Corporate Community Responsibility, Business Strategy

\section{Introduction}

Corporations often express how they act as a good corporate citizen and serve the communities they operate. Firms increasingly consider community relations as part of corporate social responsibility (CSR) and publicly advertise their engagement with communities because well-designed community engagement programs could improve firm reputation, transparency, financial capacity as well as contribute to local sustainability. ${ }^{1}$ Especially for the firms in consumer-oriented industries where consumer relations are critical, community engagement focusing on consumers who could be important stakeholders could play an important role in growing their customer base. Therefore, community relations are a strategic concern for firms and shareholders.

\footnotetext{
${ }^{1}$ See, for example, Barnett and Salomon (2006), Cochran (2007), Esteves (2008), and Byun and Oh (2018).
} 
Despite the strategic importance of community relations, there is little evidence in the literature regarding the economic impacts and motivations for community relations. ${ }^{2}$ Many existing studies discuss a firm's CSR performance rather focus on entire CSR than community relations. In addition, they suggest mixed conclusions on CSR with respect to firm performance, no relationship (McWilliams and Siegel, 2000), a positive relationship (Waddock and Graves, 1997), and a negative relationship (Wright and Ferris, 1997). Indeed, as Margolis et al. (2007) and Byun and Oh (2018) suggest, not all CSR activities create value for shareholders. Therefore, this paper examines whether a particular aspect of CSR, corporate community responsibility (CCR), can benefit firms and their shareholders.

As Carroll (1979, 1991) conceptualizes and revisits by building types of corporate social responsibility in economic, legal, ethical and discretionary (later revisited as philanthropic) responsibilities, CSR is organized in a pyramid construct (Figure 1), starting from most basic economic responsibility to the philanthropic responsibility. Philanthropic responsibility, which is placed in the highest level of desired responsibility in Carroll's (1991) pyramid construct, is to contribute to the 'community' and improve the quality of life. In addition, over time, social issues are developed and changed and companies recently show their interests not only on the basic economic and legal aspects of it but also on the desired ethical and philanthropic aspects.

Relatedly, corporate engagement with communities provides considerable resources to communities (Brammer and Millington, 2003; Griffin, 2008; Hansen, Sextl and Reichwald,2010). According to Community Development Financial Institutions (CDFIs), community investment grew up continuously and assets held for the community investment in the US is totaled $\$ 64.3$ billion. At a narrower level, corporate giving of more than 250 leading US companies amounted to $\$ 23.8$ billion in cash and product giving, of which $15 \%$ went to community and economic development programs and $28 \%$ went to education programs (CECP 2018). As a result, communities may pressure firms to get the benefits without

\footnotetext{
${ }^{2}$ Poor community relations can create a variety of costly problems (Barnett and Salomon, 2006). For example, a firm with poor community relations may face 'not-in-my-back-yard' (NIMBY) protests when attempting to open new plants, which could lower the ability of a firm's operation in communities and make it difficult to get a permit from local governments (Dear, 1992; Sellers, 1993).
} 
bearing much of the costs, raising conflicts between management and shareholders if management take the pressure for its own reputation - i.e., agency costs (Masulis and Reza, 2015). Additionally, corporate insiders and non-insiders have different interests with respect to CSR, creating conflicts among shareholders (Barnea and Rubin, 2010). Since justifying CSR or more precisely CCR investments based on a risk-reward metrics may not be suitable, sustainable and persistent CCR activities require a tremendous support from shareholders. We thus investigate what types of shareholders within a firm pursue CCR and why they promote the community investments (i.e. CCR). We especially focus on the role of local shareholders - local mutual funds - on CCR because local shareholders are likely to work in the communities they live and could have more interests in improving their neighborhoods than other shareholders. And therefore, local shareholders can be effective monitors with better internal governance strategy.

In this regard, our study proposes a new framework to the CSR literature. Departing from previous studies that focus on firm managers' characteristics and private benefits to explain firms' CSR investments (Masulis and Reza, 2015; Cheng et al., 2016; Cronqvist and Yu, 2017), we show that shareholders play a significant role in allocating capital to CSR, especially towards CCR. While Dyck et al. (2018) and Chen et al. (2016) also discuss about the impact of institutional shareholders on a firm's CSR policy, we specifically focus on local institutional shareholders and their role in a firm's community engagements.

Our study also investigates the effects of ownership structure on CSR. Previous studies show that different types of shareholders have different motivations and benefits toward firms' CSR engagements (Barnea and Rubin, 2010; Li and Zhang, 2010; Oh and Chang, 2011). Complex ownership structure creates conflicts among shareholders with respect to CSR. Managers may overinvest in CSR for their own benefits, while stakeholders may not bear costs for CSR. We look at another dimension, proximity, in ownership structure that could explain a firm's CSR. To the best of our knowledge, this study is the first to investigate the role of local shareholders as a driving force of a firm's community investments. 
Finally, a growing body of literature suggest that geographical proximity between investors and their investments creates economic benefits. ${ }^{3}$ Investors prefer local firms mainly due to their information advantages, acknowledging that the physical distance could alleviate information costs. We provide additional evidence of local ownership for value creation that local shareholders look for community engagements and thereby increase firm value.

The rest of the article is organized as follows. First, we present theoretical frameworks based on a review of literature and hypotheses development. Next, we present the data and sample then we explain empirical results. Finally, the implication of the findings are discussed and we conclude.

\section{Theoretical Frameworks and Hypotheses Development}

\section{Corporate Social Responsibility}

A wide range of debate on corporate social responsibility (CSR) has started being discussed since early 1900's (Clark, 1939; Kreps, 1940; Bowen, 1953; Carroll, 1979). The term corporate social responsibility was described in Bowen (1953)'s book, that is titled as Social Responsibilities of the Businessman. And it has been defined in various ways starting from economic perspective in order to create wealth of shareholders (Friedman, 1962) to legal, ethical and philanthropic responsibility (Carroll, 1979) and to many more. In addition, this topic has grown significantly in the most recent decades and researchers discuss more broad range of its concepts from social, political, environmental types of responsibilities. Nevertheless, there still is not a generally accepted and/or completely reliable theoretical framework to explain corporate social responsibility in terms of its concept and the activity of the economic entities, such as corporations and stakeholders. Out of various CSR conceptualizations, Carroll (1979)'s four-part definition of CSR is well grounded in the literature that give robustness throughout studies developed over time. Carroll $(1979,1991)$ develops and revisits the four types of CSR by suggesting a pyramid construct

\footnotetext{
${ }^{3}$ See, for example, Coval and Moskowitz (1999, 2001), Ivkovic and Weisbenner (2005), Baik et al. (2010), and Hwang (2018).
} 
(Figure 1) based on the layer of its development from the most fundamental to philosophical component: economic, legal, ethical and discretionary (philanthropic in his revision made in 1991). The first category of CSR is economic responsibility that entails an actual return on investment to the owners and shareholders by promoting technological advancement, making innovation, and by creating new products. Economic responsibility provides the most fundamental role of CSR. In the next layer, the legal component of responsibility is placed and it emphasizes rules and regulations under which business must operate by providing with "codified ethics" as part of the historical development of the CSR. In its third layer, ethical responsibilities are emphasized. Although first two conducts already embed the ethical components, ethical responsibility entails embrace first two and take a step further to establish environmental and civic rights that could be resulting in after first two conducts are readily set up. Finally, on top of the pyramid construct of Carroll (1991), philanthropic responsibilities are placed. This layer of responsibility exists in response to society's expectation that is beyond the basic and to the welfare of human being. The highest pyramid of corporate social responsibility can be achieved by becoming a good corporate citizen that contribute resources to the community, as community desires firms voluntarily contribute its financial and human resources in order to promote human welfare. Although these four types of responsibilities are not mutually exclusive, different responsibilities provide different motivations as well as different level of consideration. Also, economic, legal and ethical responsibilities are historically focused by the companies and market participants. However, philanthropic programs aren't considered important until recently and now, the voluntary conduct focusing on the community development is encouraged to the firms.

[Insert Figure 1 here]

\section{Corporate Community Responsibility}

Carroll $(1979,1991)$ 's philanthropic responsibility, that is a discretionary expectation aspect of CSR is in line with Barnett's (2007) definition of CSR: "a discretionary allocation of corporate resources to improving special welfare that serves as a means of enhancing relationship with key stakeholders." Recent studies of CSR focus on the communities and environments where they operate (Magali and Michael, 2004; Harris, 2007). Rowe et al. (2013) focus on the importance of corporate community partnership to 
meet the needs of the local community. As researchers and practitioners pay attention to from the mandated economic conduct to desired (Windsor, 2001) philanthropic conduct, the investment in community became a major issue to head on. In response to this historical move, companies now strategically invest their resources for the service to the community rather than a source of profit to its owners (Cochran, 2007). And the principle behind community investment is to strengthen local communities. A variety of studies find that firms that make effort in improving community relations achieve not only higher financial performances (Hillman and Keim, 2002; Preston and O’Bannon, 1997; Simpson and Kohers, 2002; Waddock and Graves, 2000) but also successful bargaining with local government officials (Waddock and Graves, 1997) and decreasing attacks by the shareholders (Rehbein et al., 2004).

\section{Stakeholder Theory and Local Shareholder Approach to CCR}

As CSR concept develops and the responsibility and beneficiary of it is keenly related, the link between the idea of corporate social responsibility and the organizational stakeholders is gained attention. Stakeholder theory, according to Freeman (1984), is defined as "those groups who can affect or are affected by the achievement of an organization's purpose" and this has become the nature of the firms to consider the creation of values per different entities without limited to the owner of the companies. And the nature of stakeholder is going beyond the traditional pool of owners and employees and extends to the customers, public in general, and to whom the companies are responsible for such as competitors, suppliers, and social activist groups (Carroll, 1991; Freeman, 1991; Jawahar and McLaughlin, 2001). Given that stakeholder theory offers a new way to organize its boundaries of responsibility not only to the owners who directly seek for the monetary return on investment but also to the silent stakeholders such as local communities, customers and public in general (Jamali, 2008). A stakeholder approach, used by Papasolomou et al. (2005), CSR actions are divided by vis-à-vis key stakeholders. Amongst a variety of stakeholders' expectations, investors tend to expect a competitive return on investment with a fair business practices. However, consumers as a silent group of stakeholders, they also expect trustworthy and quality products and services without false and misleading conducts. As consumers can be part of the stakeholders, we posit that the 
effect of CSR (and CCR) will be prominent to the consumer focused industry. Investors, as stakeholders, though expect and pursue the financial return on investment, they have motivation to enhance firms to boost community investment as a tool of improving their financial performances as well as their philanthropic performances. Despite a number of studies that emphasize the importance of community investment and the expectation of investors and consumers, there is no previous study that bridges the gap to explain as to who plays the major role to enhance community investment as part of the shareholders.

In this regard, we discuss potential channels through which shareholders influence a firm's CCR investment: local investors. There are some distinctive features for local shareholders, relative to distant shareholders, with which they could influence corporate CCR practices. Studies find that local investors are effective monitors and actively participate in firm operations through corporate governance (John, Knyazeva and Knyazeva, 2011; Chhaochharia et al., 2012; Hwang, 2018). Firms with high local ownership have better internal governance (Lerner, 1995). Accordingly, managers of high local ownership firms are less likely to engage in empire building and lead the quiet life. These findings suggest that local shareholders could prevent managers from investing in CCR for their own profits and avoid agency costs. Therefore, local shareholders strategically allocate corporate resources to CCR and help improve shareholder value. In addition, local shareholders could have frequent face-to-face meetings with executives, visiting product facilities, speaking with employees, and understanding the local economy better (Chen, Dong and Lin, 2016), which could alleviate communication costs as well as information gathering costs. ${ }^{4}$ It would facilitate local shareholders to comprehend a firm's investments including CCR that requires shareholder support. Finally, local shareholders are more likely to belong to the community networks and spread the firm's social efforts and community relations. ${ }^{5}$ Increasing the awareness of a firm's effort for community investments eventually benefits the firm financially.

\footnotetext{
${ }^{4}$ See, for example, Coval and Moskowitz (1999) and Teo (2009).

${ }^{5}$ The stakeholders' awareness of CSR is the key channel through which financial benefits are obtained (McWilliams and Siegel, 2001; Servaes and Tamayo, 2013; Byun and Oh, 2018).
} 
We thus investigate whether local shareholders facilitate and promote investments in CCR. Using mutual fund and CCR data, we find that local shareholders are likely to increase CCR. It is interesting that among other CSR activities - community, corporate governance, diversity, employee relations, environment, human rights, and product - CCR is positively associated with local ownership. ${ }^{6} \mathrm{We}$ control for those variables from CSR literature that affect a firm's CSR activities. ${ }^{7}$ Especially, we separate local shareholders from institutional shareholders, which is a proven driving force of CSR investments (Chen et al., 2016; Dyck, Lins, Roth and Wagner, 2018). Our results suggest that one standard deviation increase in local ownership is associated with an increase in CCR by around $21 \%$. Community relations are important particularly for firms in the consumer-oriented industries so that local shareholders are expected to push more investments in CCR for those firms. Consistent with the hypothesis, the positive relation between local ownership and CCR is more pronounced for the consumer-oriented firms. Thus, our first hypotheses are stated as follows:

Hypothesis 1a. Local shareholders tend to promote CCR.

Hypothesis 1b. The positive relation between local ownership and CCR is more pronounced for the consumer oriented firms.

Next, we investigate possible motivations of local mutual funds for CCR. As local investors' expectation is to achieve financial return on investment, their engagement to enhance local community responsibility will enhance financial performance. In this regard, we posit that higher CCR firms financially perform better, especially in consumer-oriented industries where CCR could bring their impact the most. ${ }^{8}$ Higher CCR firms are likely to have greater Tobin's Q and generate larger operating cash flows, which contributes to shareholder value. Secondly, local shareholders (i.e., local mutual funds) of the higher CCR firms receive greater fund flows. The finding remains the same even after controlling for fund

\footnotetext{
${ }^{6}$ Environmental activities are also positively associated with local ownership.

${ }^{7}$ See, for example, Dye (1985), Skinner (1997), Kothari et al., (2005), Barnea and Rubin (2010), and Dhaliwal et al. (2011).

${ }^{8}$ This explanation is consistent with Coval and Moskowitz (2001) and Teo (2009) that the physical presence of investors helps them perform better in a local area.
} 
characteristics such as fund performance. This result suggests that local mutual funds tend to attract more investors as they represent firms that engage more in community relations. Our second hypotheses are, thus as follows:

Hypothesis 2a. CCR is positively related to a firm performance.

Hypothesis $2 \mathbf{b}$. CCR is positively related to a positive fund flow.

\section{Data and Summary Statistics}

\section{Data and Sample Selection}

We use data from following sources, such as financial accounting data from Compustat, market data and mutual fund characteristics from CRSP, CSR and CCR related data from Kinder, Lydenberg, and Domini (KLD) and mutual fund holdings and institutional ownership data from Thomson Reuters. ${ }^{9}$ We begin with 24,561 firm-year observations for all firms covered by the firm of KLD over 2004-2013. ${ }^{10}$ Then we remove 9,102 observations due to no CSR scores in KLD. In addition, we delete firms if financial accounting data is not available. Lastly, for our further investigation of consumer-oriented industry, we require that all firm-year observations have necessary non-missing financial information for control variables and non-missing Fama-French 48-industry classification. ${ }^{11}$ The procedures above results in a final sample of 8,136 firm-year observations for the final sample from 2005-2013. To mitigate the effect of extreme outliers, all continuous variables are winsorized at the top and bottom one percentile.

\section{Variable Measurement}

\footnotetext{
${ }^{9}$ Securities and Exchange Commission (SEC) requires an institutional investment manager that exercise investment discretion over $\$ 100$ million or more in Section 13(f) securities to report its holdings on Form 13F.

${ }^{10}$ Although the original sample period is 2004-2013, our main regressions run from 2005 to 2013 due to using lagged variables as control variables.

${ }^{11}$ For consumer-oriented industries, we include 1. Agriculture, 2. Food products, 3. Candy and soda, 4. Beer and Liquor, 5. Tobacco Products, 6. Recreation, 7. Entertainment, 8. Printing and Publishing, 9. Consumer Goods, 10. Apparel, 11. Healthcare, 12. Medical Equipment, 13. Pharmaceutical Products, 16. Textiles, 22. Electrical Equipment, 23. Automobiles and Trucks, 24. Aircraft, 33. Personal Services, 34. Business Services, 38. Business Supplies, 40. Transportation, 41. Wholesale, 42. Retail, 43. Restaurants, Hotels, Motels, 44. Banking, 45. Insurance, 46. Real Estate, 47. Trading, based on Fama-French 48 industry classification.
} 


\section{Corporate Community Responsibility}

We use the KLD database to measure CSR score and CCR score. We construct CSR score based on seven dimensions: community, corporate governance, diversity, employee relations, environment, human rights, and product. We summarize the total CSR strengths and concerns from the seven dimensions first and then calculate a net CSR score as the total CSR strength minus the total CSR concerns. CCR is a net community score that is the community strength minus the community concern. To make these two CSR measures comparable between years, we standardize these scores for each year (Kotchen and Moon, 2012). We calculate the standardized CSR (STDCSR) and CCR (STDCCR) as a net CSR and a net CCR for each firm per year minus their means across firms for the same year, divided by their standard deviations, respectively.

\section{Local Mutual Fund Ownership and Other Control Variables}

We calculate actual distances between mutual funds and their portfolio firms based on the addresses of the headquarters. There are several ways to compute geographical distances, such as the geodesic distance (the shortest distance between two points on the surface of a sphere) and the driving distance. The local distance calculation in this study employs the geodesic distance; however, the results are not different when using the driving distance. We define local shareholders as mutual funds investing in a firm within a 100-kilometer of their headquarters. Coval and Moskowitz $(1999,2001)$ suggest a 100-kilometer metric among several location metrics that, in most cases, are qualitatively and quantitatively similar. Since a firm could have multiple local mutual funds, the sum of local fund ownership for each firm is used as the primary variable of interest (Local). We also have alternative measure, Local/Total, calculated as the sum of local fund ownership divided by total institutional ownership, with which we show the proportional ownership of local institutional shareholders over overall institutional shareholders.

We control for variables pertaining to firm characteristics and CSR characteristics. The firm characteristic variables are retrieved from Compustat, including firm size (Size), the book-to-market ratio

$(B M)$, return on asset $(R O A)$, leverage ratio and capital expenditures (CAPEX). Given the skewed 
distribution of total assets, we proxy Size with logged total assets. Following Kothari, Leone and Wasley (2011), we measure financial reporting quality with the absolute discretionary accruals (|DACC|) to control for potential earnings management. Specifically, we measure discretionary accruals as the residuals from the performance-adjusted modified Jones model. ${ }^{12}$

We also add control variables from CSR literature, including litigation risk (Litigation), competitive pressure (Competition), financing activities (FIN) and global presence (Global) from the CSR literature (e.g., Dhaliwal et al., 2011). Liquidity is controlled because managers are motivated to increase liquidity for selling shares from their compensation plans. Liquidity is calculated as the number of shares traded in the year to the total shares outstanding at the year-end. Following Dye (1985), competition is controlled as competition amongst industries could reduce CSR activities and CSR disclosure. Competition is proxied with Herfindhal-Hirshman Index multiplied by -1 . Followed by Skinner (1997), litigation is added as control variable as firms that are riskier tend to preempt potential lawsuits by making CSR disclosure. Litigation is an indicator variable that equals 1 if a firm operates in high-litigation industries (SIC codes of 2833-2836, 3570-3577, 3600-3674, 5200-5961, and 7370) and 0 otherwise. As per Dhaliwal et al. (2011), we further add FIN and Global as control variables. FIN is calculated as the sale of common and preferred shares minus the purchase of common and preferred shares plus the long-term debt issuance minus the long-term debt reduction. Global is an indicator variable that equals 1 if a firm reports foreign income and 0 otherwise. All detailed variable definitions are in the Appendix.

\section{Descriptive Statistics}

Table 1 reports descriptive statistics. Local has a mean of 0.0124 with standard deviation of 0.0262 . Local/Total has a mean of 0.0158 with standard deviation of 0.0330 . On average, mean CSR score and CCR score are -0.3513 and 0.812 , respectively. The negative CSR score represents that concerns exceed strengths. Descriptive statistics for all control variables are consistent with those reported in CSR literature.

\footnotetext{
${ }^{12}$ Kothari, Leone and Wasley (2005) test whether a performance-matched discretionary-accrual approach (a type of control sample approach) is both well specified and powerful at estimating discretionary accruals. The paper uses ROA as the matching variable. Detailed descriptions of this measure are explained in the Appendix.
} 
[Insert Table 1 here]

\section{Research Design and Findings}

\section{Do Local Shareholders Promote Corporate Community Responsibility?}

In this section, we investigate whether local shareholders lead firms to invest in CSR practices locally. We also test a causal relationship with an identification strategy.

\section{Local Ownership and Corporate Community Responsibility}

First, our main regression tests the associations between local ownership and CCR. Based on our hypothesis where local shareholders encourage CCR, the model specifications are as follows.

$$
\begin{aligned}
& \operatorname{STDCSR}(S T D C C R)_{t} \\
& =\alpha_{0}+\alpha_{1} \text { Local }_{t-1}\left({\text { Local } \left./ \text { Total }_{t-1}\right)}\right) \alpha_{2} \log \left(\text { Size }_{t-1}\right)+\alpha_{3} \text { BM }_{t-1}+\alpha_{4} \text { Leverage }_{t-1} \\
& +\alpha_{5} \text { ROA }_{t-1}+\alpha_{6} \mid \text { DACC }_{t-1}+\alpha_{7} \text { CAPEX }_{t-1}+\alpha_{8} \text { Liquidity }_{t-1}+\alpha_{9} \text { Compesation }_{t-1} \\
& +\alpha_{10} \text { Litigation }_{t-1}+\alpha_{11} \text { FIN }_{t-1}+\alpha_{12} \text { Global }_{t-1}+\alpha_{13} I_{t-1}+\text { Year }+ \text { Industry } \\
& +u_{t}
\end{aligned}
$$

Our dependent variable is STDCSR (STDCCR), measured as standardized CSR (CCR). The primary variables of interest are Local and Local/Total, the sum of mutual fund ownership and the sum of mutual fund ownership over total institutional ownership, respectively. Control variables are detailed in Appendix. All specifications are controlled for year and industry fixed effects.

Table 2 reports the multivariate regressions of CSR and CCR on local shareholders. We compare CSR with CCR and test whether local shareholders encourage CCR or entire CSR. Panel A reports the estimates for all industries, while Panel B shows only consumer-oriented industries. In Column (1) and (2) of Panel A, we regress STDCSR and STDCCR on Local and control variables. The coefficient estimate of Local is negative and insignificant with STDCSR, while it is positive and significant at the $1 \%$ level with STDCCR. The results suggest that local shareholders tend to increase CCR rather overall CSR. The coefficient estimates on Local in Column (2), 1.3479, indicates that one-standard deviation increase in local 
ownership raises CCR by around $21 \% .{ }^{13}$ We also estimate the model specifications with an alternate local ownership variable, Local/Total. The variable of interest reflects the investment proportions of local shareholders among institutional investors. The results remain the same, suggesting firms with higher local ownership are likely to increase CCR.

In Panel B, we run a sub-sample analysis only with consumer-oriented industry firms. The industry classifications follow Fama-French 48-industry classification. Community relations are critical especially for the firms in the consumer-oriented industries. Therefore, we expect that the associations between local shareholders and CCR are more pronounced. Consistent with the hypothesis, the coefficient estimates of Local and Local/Total are greater and statistically significant at the 1\% level. As for STDCSR, the coefficients remain negative and insignificant.

\section{[Insert Table 2 here]}

\section{Why Do Local Shareholders Promote Corporate Community Responsibility?}

In this section, we ask why then local shareholders promote corporate community responsibility. What are the motivations behind CCR practices? Is there any economic benefit? To answer these questions, we investigate what matters the most to the local shareholders. Our local shareholders are mutual funds investing in local firms. The two most important indicators that measure the quality of mutual funds are fund performance and fund flows. As local shareholders are especially concerned with fund performance and fund flows like any other mutual funds, we expect that their strategical practices imposed on portfolio firms are likely to benefit fund performance and fund flows. Therefore, this section examines whether CCR activities help the local shareholders deliver better performance and higher fund flows or whether they simply cost them due to no economic benefits.

\section{Firm Performance}

\footnotetext{
13 The dependent variable in the model is STDCCR. Following the definition of STDCCR, we compute the amount to which local ownership increases CCR. Ceteris paribus, one-standard deviation increase in local ownership raises CCR by about $0.0174(21 \%)$ from the mean.
} 
To test fund performance, we rather focus on firm performance instead of fund performance because of two reasons. First, overall fund performance is measured with not only the performance of local firms, but also distant firms. We thus cannot distinguish the performance of mutual funds as local shareholders or distant shareholders. Secondly, we cannot separate fund performance based on a portfolio firm's CCR policy or any other investment policies. It is highly possible that a firm performs well not because of its CCR, but because of its other strategical practices. Therefore, our empirical approach is to examine a relationship between a firm's performance and its CCR policy imposed by local shareholders directly. Since overall fund performance is comprised of its portfolio firms' performance, higher firm performance due to CCR investment would lead to better fund performance. Therefore, our estimation model is as follows.

Tobin's $Q_{t}\left(O C F_{t}\right)$

$=\alpha_{0}+\alpha_{1} \operatorname{STDCCR}_{t-1}+\alpha_{2} \log \left(\right.$ Size $\left._{t-1}\right)+\alpha_{3} B M_{t-1}+\alpha_{4}$ Leverage $_{t-1}+\alpha_{5}$ ROA $_{t-1}$

$+\alpha_{6}|D A C C|_{t-1}+\alpha_{7}$ CAPEX $_{t-1}+\alpha_{8}$ Liquidity $_{t-1}+\alpha_{9}$ Compesation $_{t-1}$

$+\alpha_{10}$ Litigation $_{t-1}+\alpha_{11}$ FIN $_{t-1}+\alpha_{12}$ Global $_{t-1}+\alpha_{13} I_{t-1}+$ Fixed Effects

$+u_{t}$

We measure the firm performance with two distinctive variables, Tobin's $Q$ and operating cash flows $(O C F)$. Tobin's Q represents investors' expectations about the risk-adjusted future cash flows of a firm, which is considered as an equivalent measure of a market-to-book ratio (Anderson and Reeb, 2003; Cheng, 2008). Our second measure for firm performance, $O C F$, is calculated as operating cash flows scaled by total assets. It is less influenced by accrual accounting methods (Vorhies, Morgan and Autry, 2009), captures variation in organizational performance (Otley and Fakiolas, 2000) and provides incentives to market participants with value-relevant information (Defond and Hung, 2003). Our model specifications also include the control variables in Equation (1).

We report the regression results of both CSR and CCR on firm performance in Table 4. First two columns of Panel A show that CSR investments (measured with STDCSR) tend to increase firm 
performance in overall industries. ${ }^{14}$ The results are consistent with recent CSR literature that CSR practices produce better firm performance. ${ }^{15}$ This verifies that our sample is not distant from the existing studies. The last two columns provide evidence that CCR practices lead to higher firm performance. The coefficients of STDCCR are positive and significant at the $1 \%$ level for Tobin's Q and the $5 \%$ level for $O C F$, respectively. The coefficient estimates suggest that one standard deviation increase in $C C R$ raises Tobin's $\mathrm{Q}$ by around $7 \%$ and generates about $\$ 17.7$ million additional operating cash flows. ${ }^{16}$ In Panel $\mathrm{B}$, the magnitude of the impact on firm performance becomes larger when it comes to consumer-oriented firms. It is consistent with our findings so far that community investments are critical and could extend the customer base especially for those direct consumer-relation firms.

Previous literature explains some possible explanations why a firm's community investments increase firm performance. First, CCR activities are locally focused so that community members as well as stakeholders recognize the firms' social efforts in their communities. The key channel of the shareholder (or the stakeholder including community) maximization theory is the awareness of a firm's social investments. ${ }^{17}$ Secondly, local shareholders could push their closely held firms to spend community-related investments more strategically in their areas. Even though not all CSR investments are strategical, local shareholders allocate their community investments more efficiently and strategically in exchange for future returns due to their information advantage in the community. Finally, local media could help deliver better firm performance because consumers in the area could expose themselves to more products and services provided by high CCR firms due to media coverage (Byun and Oh, 2018).

[Insert Table 3 here]

\section{Fund Flows}

\footnotetext{
${ }^{14} \mathrm{We}$ also investigate other categories of CSR practices and their effects on firm performance, as overall CSR activities increase firm performance significantly. Based on KLD classifications, employ relations and product-related issues improve firm performance.

${ }^{15}$ See Edmans (2011), Deng et al. (2013), Flammer (2013), and Servaes and Tamayo (2013).

${ }^{16}$ We compute the additional amount of the operating cash flows with the mean of total assets $(\$ 8,471,110,000)$.

${ }^{17}$ See, for example, McWilliams and Siegel (2001), Schuler and Cording (2006), Fisman et al. (2008), Du et al. (2010), and Servaes and Tamayo (2013)
} 
Next, we investigate whether CCR activities help deliver greater fund flows for local shareholders. The mutual fund literature has extensively examined the flow-performance relationship. Some researchers argue that fund flows generally respond to past performance (Chevalier and Ellison, 1997; Berk and Green, 2004), while others suggest that fund flows are simply a result of a fund's marketing effort, not related to fund performance (Jain and Wu, 2000). Or both, prior performance and search costs (Sirri and Tufano, 1998). We propose that CCR practices could enhance fund flows in both ways.

Based on our findings, CCR policy tends to increase firm performance, which would consequently benefit funds with higher performance. This obviously satisfies fund investors and thus will attract more investors - i.e. larger fund flows. In addition, local shareholders advertise CCR practices for themselves as a marketing tool - advertisement to community members. Sirri and Tufano (1998) show that fund flows are directly related to media attention by the fund due to a decrease in consumers' search costs. Consistent with the finding, as local media publicizes the social efforts of firms and their shareholders on community development, it is likely to increase the awareness of members of the community. This in turn could help deliver more money flows to local shareholders.

It is yet possible that fund investors are more worried about their funds' social investments which could result in uncertain outcomes. Investing in firms with high social investments likely to reduce the set of investment opportunities and increase monitoring costs, which would negatively affect fund performance and thus discourage investors to join the funds (Geczy et al., 2005; Renneboog et al., 2008; Cortez et al., 2009). Therefore, it is an empirical question to investigate the impacts of CCR on fund flows for local shareholders. We estimate the following model.

$$
\text { Fund Flows } \text { F }_{t}=\alpha_{0}+\alpha_{1} \text { STDCCR }_{t-1}+\alpha_{2} \text { Fund Controls }_{t-1}+\text { Fixed Effects }+u_{t} \text {, }
$$

We measure annual fund flows as:

Fund Flows $s_{j, t}=\frac{T N A_{j, t}-T N A_{j, t-1}\left(1+R_{j, t}\right)}{T N A_{j, t-1}}$,

where $T N A_{j, t}$ and $T N A_{j, t-1}$ are the total net assets for fund $j$ at the end of years $t$ and $t-1$, respectively, and $R_{j, t}$ is the return of fund $j$ in year $t$. Fund Controls include variables that measure fund characteristics such 
as fund performance, $12 \mathrm{~b} 1$ fees, expense ratio, turnover ratio, and fund age. ${ }^{18} \mathrm{We}$ also control for year fixed effects.

Table 5 reports the regression results. The depend variables are Fund Flows and Scaled Fund Flows (scaled by the number of local mutual funds). Our variable of interest is STDCCR. The coefficient estimates are positive and significant with or without fund control variables, implying that a firm's CCR activities tend to increase fund flows to local shareholders. Local shareholders employ CCR policy as investment strategy and a marketing tool to enjoy greater fund flows.

[Insert Table 4 here]

\section{Controlling for Endogeneity of Local Ownership}

So far we find that local ownership increases CCR. However, an endogeneity of mutual fund ownership may create a spurious relationship between the local ownership and CCR. It is possible that local shareholders selectively invest in firms that spend on CCR - reverse causality. To resolve the endogeneity concern, we employ a regression discontinuity (RD) design with Russell indexes. ${ }^{19}$ On May $31^{\text {st }}$ each year, firms are assigned to the Russell indexes based on their market capitalization rankings. ${ }^{20}$ This index assignment is near random around the Russell 1000/2000 threshold and exogenous to firm characteristics such as CSR policy, while it leads to portfolio rebalancing by institutional shareholders that benchmark against the Russell indexes, especially at their threshold (Chen et al. 2016; Crane, Michenaud and Weston, 2016; Hwang, 2018). ${ }^{21}$

Our identification strategy to resolve the concern considers the inclusion of Russell 2000 index as a source of exogenous shocks to local mutual fund holdings. The Russell indexes are value-weighted indexes, consisting of the largest one thousand U.S.-listed firms based on market capitalization on May $31^{\text {st }}$

\footnotetext{
${ }^{18}$ We calculate fund performance as annual returns and fund age as the natural logarithm of fund age (the age of the oldest share class of the mutual fund measured in months since the inception date).

${ }^{19}$ The regression discontinuity design is a quasi-experimental design that investigates the casual effects of instrument variables by assigning a cutoff or threshold above or below which an instrument is assigned.

${ }^{20}$ The Russell indexes are popular benchmark indexes for institutional investors, including Russell 1000 with the largest one thousand firms and Russell 2000 with the next two thousand firms.

${ }^{21}$ The smallest hundred firms in the Russell 1000 have a combined index weight of $0.99 \%$, while the largest hundred firms in the Russell 2000 have a combined index weight of $17.47 \%$.
} 
each year for Russell 1000 and subsequent largest two thousand firms for Russell 2000. Then Russell uses its June float-adjusted market capitalization to calculate the index weights. ${ }^{22}$ Because of the value-weighted index design, there are significant differences in index weights for smallest firms in Russell 1000 and largest firms in Russell 2000.

Figure 2 plots the index weights for smallest 250 firms in Russell 1000 and largest 250 firms in Russell 2000, where a zero represents the thresholds for Russell 1000/2000 (1000 ${ }^{\text {th }}$ largest firms). It shows that the Russell indexes threshold at which firms are assigned to either Russell 1000 or Russell 2000 creates a large discontinuity in index weights. Therefore, the Russell indexes threshold could be a good candidate for an instrument variable that generates exogenous variation in local mutual fund holdings but seems orthogonal to a firm's community investments.

Recent papers, however, point out some endogeneity concerns and challenges for the identification strategy due to Russell's policy that determines index memberships and weights (Crane et al., 2016; Appel et al, 2018; GloBner, 2018; Wei and Young, 2018). After membership is determined by the end-of-May market capitalization, stocks within indexes are adjusted to include only those shares available to the public, referred to as "free float." This aims to exclude shares that are not available for purchase, and Russell indexes are weighted by this so-called float-adjusted market capitalization. Consequently, firms with lower float-adjusted market capitalization (i.e., lower liquidity and higher inside ownership) move toward the bottom of the Russell 1000, while those with higher float-adjusted market capitalization (higher liquidity and lower inside ownership) occupy at the top of the Russell 2000. This could lead us incorrectly to attribute observed differences to index assignment rather than to the underlying differences in liquidity and inside ownership (Appel et al., 2016, 2018).

\footnotetext{
22 That is, the indexes membership is determined by the end-of-May market capitalization, and the index weight for each stock within indexes is calculated with the June float-adjusted market capitalization. The float-adjusted market capitalization only includes the value of shares available to the public. Therefore, the $1,000^{\text {th }}$ largest stock in the endof-May market capitalization needs not be the smallest index weight stock in the Russell 1000 index. This creates some endogeneity issues for the identification strategy. See, for example, Appel et al. (2016, 2018), Crane et al. (2016), GloBner (2018), and Wei and Young (2018).
} 
In addition, Russell has changed its methodology since 2007 to mitigate unnecessary turnover. Beginning in June 2007, Russell implements a banding methodology in which stocks within a certain range of the cutoff would not move in or out of the Russell 1000/2000 indexes. The reconstitution methodologies add issues and challenges to current researches using the indexes as IV estimation. Therefore, we add three additional control variables to account for the Russell's new policy: (1) an indicator variable that a firm will not switch indexes in reconstitution due to the banding policy, (2) an indicator variable that a firm was a member of Russell 2000 in the previous year, and (3) an interaction term between (1) and (2). The additional control variables would capture the adjustments that occur due to the new banding policy beginning in 2007 .

\section{[Insert Figure 2 here]}

We employ a two-stage least squares (2SLS) model, following the work of Appel et al. (2018). ${ }^{23}$ Using the Russell indexes thresholds in a regression discontinuity design, the first- and second-stage specifications are as follows.

First stage:

$$
\begin{aligned}
& \text { Local }_{i, t}=\alpha+\eta_{1} \text { Russell2000 }_{i, t}+\delta_{1}\left(\text { Russell Rank }_{i, t}-1000\right)+\delta_{2} \text { Float }_{i, t}+\theta_{1} \text { Band }_{i, t}+ \\
& \theta_{2} \text { Russell2000 }_{i, t-1}+\theta_{3}\left(\text { Band }_{i, t} \times \text { Russell2000 }_{i, t-1}\right)+\tau_{1} F E_{i, t}+\omega_{i, t},
\end{aligned}
$$

Second stage:

$$
\begin{aligned}
& \text { CCR }_{i, t+1}=\kappa_{t}+\beta \text { Local }_{l, t}+\lambda_{1}\left(\text { Russell Rank }_{i, t}-1000\right)+\lambda_{2} \text { Float }_{i, t}+\chi_{1} \text { Band }_{i, t}+ \\
& \chi_{2} \text { Russell2000 }_{i, t-1}+\chi_{3}\left(\text { Band }_{i, t} \times \text { Russell2000 }_{i, t-1}\right)+\psi_{1} F E_{i, t}+\varepsilon_{i, t}
\end{aligned}
$$

The first stage estimates local mutual fund ownership as a function of the Russell indexes threshold in a RD design. The threshold creates a discontinuity in institutional holdings of shares, and especially for firms close to the cutoffs, we have a quasi-experimental design. Russell2000 ${ }_{i, t}$ is a binary treatment variable that represents inclusion in the Russell 2000 in year t. Russell Rank is a ranking variable from

\footnotetext{
${ }^{23}$ Several papers recently discussed about the best empirical design to build identification on the indexes (Appel et al., 2018; GloBner, 2018; Wei and Young, 2018). I follow the work of Appel et al. (2018).
} 
Russell indexes, based on the end-of-May market capitalization. ${ }^{24}$ We also control for the mechanical relationship with market capitalization ranking on both side of the threshold with a distance to the threshold, (Russell Rank $k_{i, t}-1000$ ), for firm $i$ in year $t$. The index weights by the June float-adjusted market capitalization is taken into the specifications as the difference between the end-of-May market capitalization and the actual rank assigned by Russell in June, Float $_{i, t}$. Finally, the three additional variables mentioned above are controlled.

The second stage estimates CCR as a function of instrumented local ownership. CCR is measured in year $t+1$ after the year of index assignment. The regression specifications include control variables in the first stage. We expect the positive effect of an exogenous increase in local ownerships in sample firms. The first and second stages control for the year fixed effects. Table 3 reports the two-stage regressions of the innovation outcome variables. Lee and Lemieux (2010) documents how to choose a bandwidth (a window around the cutoff) in a RD design. A too narrow window generates imprecise estimates, while a too wide window produces biased estimates. More importantly, a wide bandwidth makes the comparisons on both sides of the firms around the cutoff less credible since we are looking at far away firms from the cutoff, which typically diluting the effects of the discontinuity. Therefore, we provide the results in a \pm 100 bandwidth around the threshold.

In the first stage, the coefficients on the treatment variable, Russell $2000_{i, t}$, are 2.8734 in Column (1). The result suggests that the addition to Russell 2000 increases local mutual fund ownership in firms by about $2.87 \%$ on average. In the second stage, the coefficient estimate on instrumented local ownership is positive and significant at the $10 \%$ level, indicating that the increased local ownership leads to higher CCR. The annual Russell index assignments cause exogenous ownership changes, not only for local mutual funds, but also for entire institutional investors that benchmark the indexes. To differentiate shareholding changes in local ownership relative to overall institutional ownership, we use an alternate ownership variable, local fund ownership over overall institutional ownership, Local/Total, and run the same 2SLS estimations. The

\footnotetext{
${ }^{24}$ We appreciate David Pedersen and FTSE Russell for sharing the Russell indexes data.
} 
third and fourth columns report the estimation results. Overall, the inclusion of Russell 2000 index increases local fund ownership relative to total institutional ownership and thus, leads to greater CCR.

[Insert Table 5 here]

\section{Conclusion}

We investigate the role of local shareholders on a firm's CSR practices. This paper finds that local shareholders lead firms to engage in corporate social responsibility activities locally - corporate community responsibility. We find that mutual funds investing in local firms tend to increase CCR. Our identification strategy suggests a causal effect of local shareholders on CCR. Local shareholders and their firms employ CCR as business strategy and benefit themselves financially. Our results indicate that CCR tends to increase firm performance measured with Tobin's Q and operating cash flows, especially in the consumer-oriented industries where customer relations are critical. In addition, local shareholders (i.e. mutual funds) of higher CCR firms enjoy greater fund flows. 


\section{References}

Appel IR, Gormley TA, Keim DB. 2016. Passive investors, not passive owners. Journal of Financial Economics 121(1): 111-141.

Appel IR, Gormley TA, Keim DB. 2018. Identification using Russell 1000/2000 index assignments: a discussion of methodologies. Working paper.

Baik B, Kang JK, Kim JM. 2010. Local institutional investors, information asymmetries, and equity returns. Journal of Financial Economics 97: 81-106.

Barnea A, Rubin A. 2010. Corporate social responsibility as a conflict between shareholders. Journal of Business Ethics 97(1): 71-86.

Barnett ML. 2007. Stakeholder influence capacity and the variability of financial returns to corporate social responsibility. Academy of Management Review 32(3): 794-816.

Barnett ML, Salomon RM. 2006. Beyond dichotomy: The curvilinear relationship between social responsibility and financial performance. Strategic Management Journal 27(11): 1101-1122

Bebchuk L. 2005. The case for increasing shareholder power. Harvard Law Review 118(3): 835-914.

Becht M, Franks J, Mayer C, Rossi S. 2009. Returns to shareholder activism: evidence from a clinical study of the Hermes UK Focus Fund. Review of Financial Studies. 22(8):3093-3129.

Berk JB, Green RC. 2004. Mutual fund flows and performance in rational markets. Journal of Political Economy. 112(6):1269-1295.

Black B.1990. Shareholder passivity reexamined. Michigan Law Review 89(December): 520-607.

Brammer S, Millington A. 2003. The effect of stakeholder preferences, organizational structure and industry type on corporate community involvement. Journal of Business Ethics 45(3): 213-226. 
Brav A, Jiang W, Partnoy F, Thomas R. 2008. Hedge fund activism, corporate governance and firm performance. Journal of Finance 63(4): 1729-1775.

Byun SK, Oh JM. 2018. Local corporate responsibility, media coverage, and shareholder value. Journal of Banking and Finance 87: 68-86.

Chen T, Dong H, Lin C. 2016. Institutional shareholders and corporate social responsibility: evidence from two quasi-natural experiments. Working paper.

Cheng IH, Hong H, Shue K. 2016. Do managers do good with other peoples' money? Working paper.

Chevalier J, Ellison G. 1997. Risk taking by mutual funds as a response to incentives. Journal of Political Economy. 105(December): 1167-1200.

Chhaochharia V, Kumar A, Niessen-Ruenzi A. 2012. Local investors and corporate governance. Journal of Accounting and Economics 54(1): $42-67$.

Chung H, Talaulicar T. 2010. Forms and effects of shareholder activism. Corporate Governance: An International Review 18(4): 253-257.

Cochran PL. 2007. The evolution of corporate social responsibility. Business Horizons 50: 449-454.

Cortez MC, Silva F, Areal N. 2009. The performance of European socially responsible funds. Journal of Business Ethics 87(4):573-588.

Coval JD, Moskowitz TJ. 1999. Home bias at home: local equity preference in domestic portfolios. Journal of Finance 64(6): 2045-2073.

Coval JD, Moskowitz TJ. 2001. The geography of investment: informed trading and asset prices. Journal of Political Economy 109(4): 811-841.

Crane AD, Michenaud S, Weston JP. 2016. The effect of institutional ownership on payout policy: evidence from index thresholds. Review of Financial Studies 29(6): 1377-1408. 
Cronqvist H, Yu F. 2017. Shaped by their daughters: executives, female socialization, and corporate social responsibility. Journal of Financial Economics 126(3): 543-562.

Dear M. 1992. Understanding and overcoming the NIMBY syndrome. Journal of the American Planning Association 58(3): 288-300.

Dhaliwal DS, Li OZ, Tsang A, Yang YG. 2011. Voluntary nonfinancial disclosure and the cost of equity capital: the initiation of corporate social responsibility reporting. Accounting Review 86(1): 59-100.

Dimson E, O־guzhan K, Xi L. 2015. Active ownership. Review of Financial Studies 28(2):3225-3268.

Dyck A, Lins KV, Roth L, Wagner HF. 2018. Do institutional investors drive corporate social responsibility? International evidence. Journal of Financial Economics 131(3): 693-714.

Dye RA. 1985. Disclosure of non-proprietary information. Journal of Accounting Research 23(1): 123-145.

Ertimur YF, Ferri C, Stubben S. 2010. Board of directors responsiveness to shareholders: evidence from shareholder proposals. Journal of Corporate Finance 16(1): 53-72.

Esteves AM. 2008. Mining and social development: refocusing community investment using multi-criteria decision analysis. Resources Policy 33(1): 39-47.

Friends of the Earth (FOE). 2001. Confronting Companies Using Shareholder Power: a handbook on Socially-Oriented Shareholder Activism. http://www.foe.org/international/shareholder/index.html [10 July 2001].

Gaspar JM, Massa M. 2007. Local ownership as private information: evidence on the liquidity-monitoring trade-off. Journal of Financial Economics 83(3): 751-792.

Geczy C, Stambaugh RF, Levin D. 2005. Investing in socially responsible mutual funds. University of Pennsylvania working paper. 
Gillan SL, Starks LT. 2007. The evolution of shareholder activism in the United States. Journal of Applied Corporate Finance 19(1): 55-73.

Globner S. 2018. The effects of institutional investors on frim outcomes: empirical pitfalls of quasiexperiments using Russell 1000/2000 index reconstitutions. Working paper.

Godfrey PC, Hatch NW. 2007. Researching corporate social responsibility: An agenda for the 21st century. Journal of Business Ethics 70(1): 87-98.

Goodman J, Louche C, van Cranenburgh K, Arenas D. 2014. Social shareholder engagement: the dynamics of voice and exit. Journal of Business Ethics 125(2): 193-210.

Gordon L, Pound J. 1993. Information, ownership structure, and shareholder voting: evidence from shareholder-sponsored corporate governance proposals. Journal of Finance 48(2): 697-718.

Griffin JJ. 2008. Re-examining corporate community investment: Allen's Australian centre for corporate public affairs (ACCPA) corporate community involvement report. Journal of Public Affairs 8(3): 219-227.

Hansen E, Sextl M, Reichwald R. 2010. Managing strategic alliances through a community-enabled balanced scorecard: the case of Merck Ltd, Thailand. Business Strategy and the Environment 19(6): 387-399.

Hwang HD. 2018. The real effects of local investors: evidence from corporate innovation. Working paper.

Hess D, Rogovsky N, Dunfee TW. 2002. The next wave of corporate community involvement: corporate social initiatives. California Management Review 44(2): 110-125.

Ivkovic Z, Weisbenner S. 2005. Local does as local is: information content of the geography of individual investors' common stock investments. Journal of Finance 60(1): 267-306. 
John K, Knyazeva A, Knyazeva D. 2011. Does geography matter? firm location and corporate payout policy. Journal of Financial Economics 101(3): 533-551.

Karpoff J, Malatesta P, Walkling R. 1996. Corporate governance and shareholder initiatives: Empirical evidence. Journal of Financial Economics 42(3): 365-395.

Katz D. 2005. Corporate Governance: Shareholder Activism in 2004 and Implications for 2005.

Kothari SP, Leone AJ, Wasley CE. 2005. Performance matched discretionary accrual measures. Journal of Accounting and Economics 39(1): 163-197.

Kotchen M, Moon JJ. 2012. Corporate social responsibility for irresponsibility. The B.E. Journal of Economic Analysis \& Policy 12(1): 1-23.

Lerner J. 1995. Venture capitalists and the oversight of private firms. Journal of Finance 50(1): 301-318.

Lee DS, Lemieux T. 2010. Regression discountinuity designs in economics. Journal of Economic Literature 48(2): 281-355.

Levit, D. Soft shareholder activism. The Review of Financial Studies, Forthcoming, https://doi.org/10.1093/rfs/hhy119.

Li W, Zhang R. 2010. Corporate social responsibility, ownership structure, and political interference: evidence from China. Journal of Business Ethics 96(4): 631-645.

Maas K, Liket K. 2011. Talk the walk: Measuring the impact of strategic philanthropy. Journal of Business Ethics 100(3): 445-464

Margolis JD, Elfenbein HA, Walsh J. 2007. Does it pay to be good and does it matter? a meta-analysis of the relationship between corporate social and financial performance. Working paper

Margolis JD, Walsh JP. 2003. Misery loves companies: rethinking social initiatives by business. Administrative Science Quarterly 48(2): 268-305. 
Marler JH, Fauge`re C. 2010. Shareholder activism and middle management equity incentives. Corporate Governance: An International Review 18(4):313-328.

Masulis RW, Reza SW. 2014. Agency problems of corporate philanthropy. Review of Financial Studies 28(2): 592-636.

Mathews MR. 2008. Further thoughts on mega-accounting and the need for standards. Issues in Social \& Environmental Accounting 2(2):158-175.

McCahery J, Sautner A, Starks LT. 2016. Behind the scenes: the corporate governance preferences of institutional investors. Journal of Finance 71(6):2905-2932.

McWilliams A, Siegel D. 2000. Corporate social responsibility and financial performance: correlation or misspecification? Strategic management journal 21(5): 603-609.

McWilliams A, Siegel D. 2001. Corporate social responsibility: a theory of the firm perspective. Academy of Management Review 26(1): 117-127.

Oh WY, Chang YK, Martynov A. 2011. The effect of ownership structure on corporate social responsibility: empirical evidence from Korea, Journal of Business Ethics 104(2): 283-297.

Orlitzky M, Schmidt FL, Rynes SL. 2003. Corporate social and financial performance: a meta-analysis. Organization Studies 24(3): 403-441.

O'Rourke, A. 2003. A new politics of engagement: shareholder activism for corporate social responsibility. Business strategy and the environment 12(4): 227-239.

Otley, D., \& Fakiolas, A. (2000). Reliance on accounting performance measures: dead end or new beginning?. Accounting, Organizations and Society, 25(4-5), 497-510.

Parrino R, Sias R, Starks L. 2003. Voting with their feet: institutional ownership changes around forced CEO turnover. Journal of Financial Economics 68(1): 3-46. 
Porter ME, Kramer MR. 2002. The competitive advantage of corporate philanthropy. Harvard Business Review 80(12): 56-69.

Pound J. 1991. Investor protection versus market efficiency. Journal of Financial Economics 29(2): 241285.

Prevost AK, Rao RP. 2000. Of what value are shareholder proposals sponsored by public pension funds? Journal of Business 73(2):177-204.

Renneboog L, Horst T, Zhang C. 2008. Socially responsible investments: institutional aspects, performance, and investor behavior. Journal of Banking and Finance 32(9): 1732-1742.

Rowley T., Berman S. 2000. A brand new brand of corporate social performance. Business \& Society 39(4): $397-418$.

Ryan LV, Schneider M. 2002. The antecedents of institutional investor activism. Academy of Management Journal 27(4): 554-573.

Saiia DH, Carroll AB, Buchholtz AK. 2003. Philanthropy as strategy: when corporate charity " begins at home'’. Business \& Society 42(2): 169-201.

Seifert B, Morris SA, Bartkus BR. 2003. Comparing big givers and small givers: Financial correlates of corporate philanthropy. Journal of Business Ethics 45(3): 195-211.

Sellers M. 1993. NIMBY: a case study in conflict politics. Public Administration Quarterly 16(4): 460-477.

Servaes H, Tamayo A. 2013. The impact of corporate social responsibility on firm value: the role of customer awareness. Management Science 59(5): 1045-1061.

Sirri ER, Tufano P. 1998. Costly search and mutual fund flows. Journal of Finance. 53(October): 15891622. 
Skinner DJ. 1997. Earnings disclosures and stockholder lawsuits. Journal of Accounting and Economics 23(3): 249-282.

Shareholder Action Network (SAN). 2002. Disclosure of proxy votes and voting guidelines by mutual funds and investment advisers. http://www.shareholderaction.org/mutual_fund_proxy_main.cfm [15 January 2003].

Teo M. 2009. The geography of hedge funds. Review of Financial Studies 22(9): 3531-3561.

Thomas R, Cotter J. 2007. Shareholder proposals in the new millennium: shareholder support, board response, and market reaction. Journal of Corporate Finance 13(2/3): 368-391.

van der Voort JM, Glac K, Meijs LC. 2009. "Managing” corporate community involvement. Journal of Business Ethics 90(3): 311-329.

Vorhies DW, Morgan RE, Autry CW. 2009. product-market strategy and the marketing capabilities of the firm: impact on market effectiveness and cash flow performance. Strategic Management Journal 30(12): 1310-1334.

Waddock S, Graves S. 1997. The corporate social performance - financial performance link. Strategic Management Journal 18(4): 303-319.

Wei W, Young A. 2018. Selection bias or treatment effect? a re-examination of Russell 1000/2000 index reconstitution. Working paper.

Wright P, Ferris S. 1997. Agency conflict and corporate strategy: the effect of divestment on corporate value. Strategic Management Journal 18(1): 77-83. 
Appendix. Variable Definitions

\begin{tabular}{|c|c|}
\hline Variable Names & Variable Definitions \\
\hline \multicolumn{2}{|l|}{ Local Variable } \\
\hline Local & $\begin{array}{l}\text { The number of shares of a firm, held by mutual funds located within a 100-kilometer of the } \\
\text { firm's headquarter, divided by the firm's total shares outstanding in year t }\end{array}$ \\
\hline Local/Total & Local divided by total institutional ownership \\
\hline \multicolumn{2}{|c|}{ Corporate Social Responsibility Variable } \\
\hline CSR & $\begin{array}{l}\text { The net score of a firm's corporate social responsibility (CSR) rating, It is calculated as total } \\
\text { strengths minus total concerns of CSR based on seven social rating categories: community, } \\
\text { corporate governance, diversity, employee relations, environment, human rights, and product } \\
\text { (KLD STATS). }\end{array}$ \\
\hline STDCSR & $\begin{array}{l}\text { The standardized score of a firm's corporate social responsibility (CSR) rating, per Kotchen and } \\
\text { Moon (2012). It is calculated as total strengths minus total concerns of CSR for each company } \\
\text { each year and subtract the mean across companies for the same year, and divide by the standard } \\
\text { deviation, based on seven social rating categories: community, corporate governance, diversity, } \\
\text { employee relations, environment, human rights, and product (KLD STATS). }\end{array}$ \\
\hline CCR & The net score of a firm's total community rating. (KLD STATS). \\
\hline STDCCR & $\begin{array}{l}\text { The standardized score of a firm's total community rating. It is calculated as net community } \\
\text { score minus the mean across companies for the same year and divide by the standard deviation. } \\
\text { (KLD STATS). }\end{array}$ \\
\hline \multicolumn{2}{|c|}{ Firm Characteristic Variables } \\
\hline Size & The total assets (in millions) (Compustat AT). \\
\hline BM & Ratio of book value of equity to market value of equity (Compustat CEQ/(PRCC_F*CSHO)). \\
\hline Leverage & The debt to asset ratio (Compustat (DLC+DLTT)/AT). \\
\hline Tobin's Q & $\begin{array}{l}\text { The market-to-book ratio for a firm's resources, defined in CRSP/Compustat codes calculated } \\
\text { as, }\left(\mathrm{PRCC} \_\mathrm{F}^{*} \mathrm{CSHO}+\mathrm{LT}\right) /(\mathrm{CEQ}+\mathrm{LT}) \text {. }\end{array}$ \\
\hline $\mathrm{OCF}$ & Operating cash flow scaled by total assets (Compustat OANCF/AT). \\
\hline ROA & $\begin{array}{l}\text { Earnings before interest, taxes, depreciation, and amortization (Compustat EBITDA), divided } \\
\text { by the firm's average total assets (Compustat AT). }\end{array}$ \\
\hline \multirow[t]{2}{*}{$|\mathrm{DACC}|$} & $\begin{array}{l}\text { The absolute value of performance adjusted discretionary accruals (Kothari et al., 2005). It adds } \\
\text { ROA }_{\mathrm{i}, \mathrm{t}} \text { to the modified Jones model to account for the effectiveness of performance. }\end{array}$ \\
\hline & $\begin{array}{l}\qquad \mathrm{TA}_{i, t}=\delta_{0}+\delta_{1}\left(\frac{1}{\mathrm{ASSETS}_{i, t-1}}\right)+\delta_{2} \Delta \mathrm{SALES}_{i, t}+\delta_{3} \mathrm{PPE}_{i, t}+\mathrm{ROA}_{i, t}+v_{i, t} \\
\text { where TA }=(\Delta \mathrm{CA}-\Delta \mathrm{CL}-\Delta \mathrm{Cash}+\Delta \mathrm{STD}-\text { Depreciation }) ; \Delta \mathrm{CA} \text { is change in current assets; } \\
\Delta \mathrm{CL} \text { is change in current liabilities; } \Delta \mathrm{Cash} \text { is change in cash and cash equivalents; } \Delta \mathrm{STD} \text { is } \\
\text { change in debt that is included in current liabilities; Depreciation is depreciation and } \\
\text { amortization expense; all scaled by lagged total assets. ASSETS is total assets. } \Delta \mathrm{SALES} \text { is } \\
\text { change in sales revenues scaled by lagged total assets. PPE is gross property, plant, and } \\
\text { equipment scaled by lagged total assets. ROA is income before extraordinary items scaled by } \\
\text { lagged total assets. }\end{array}$ \\
\hline CAPEX & Capital expenditures scaled by total assets (Compustat CAPX/AT). \\
\hline $\mathrm{IO}$ & Institutional Ownership \\
\hline
\end{tabular}

\section{CSR Specific Control Variables}

Liquidity The ratio of the number of shares traded in the year to the total shares outstanding at the yearend (Dhaliwal et al., 2011).

Litigation An indicator variable that equals 1 if a firm operates in a high-litigation industry, which is defined based on SIC codes of 2833-2836, 3570-3577, 3600-3674, 5200-5961, and 7370 (Francis et al., 1994; Matsumoto, 2002; Dhaliwal et al., 2011).

Competition $\quad$ Equals to the Herfindahl-Hirschman Index multiplied by -1 .

FIN The sale of common and preferred shares minus the purchase of common and preferred shares (Compustat SSTK-PRSTKC) plus the long-term debt issuance minus the long-term debt reduction (Compustat DLTIS-DLTR) scaled by total assets at the beginning of the year (Compustat AT) (Dhaliwal et al., 2011).

Global An indicator variable that equals 1 if a firm reports foreign income (Compustat PIFO) (Dhaliwal et al., 2011). 
Figure 1. The pyramid of Corporate Social Responsibility revisited by Carroll (1991)

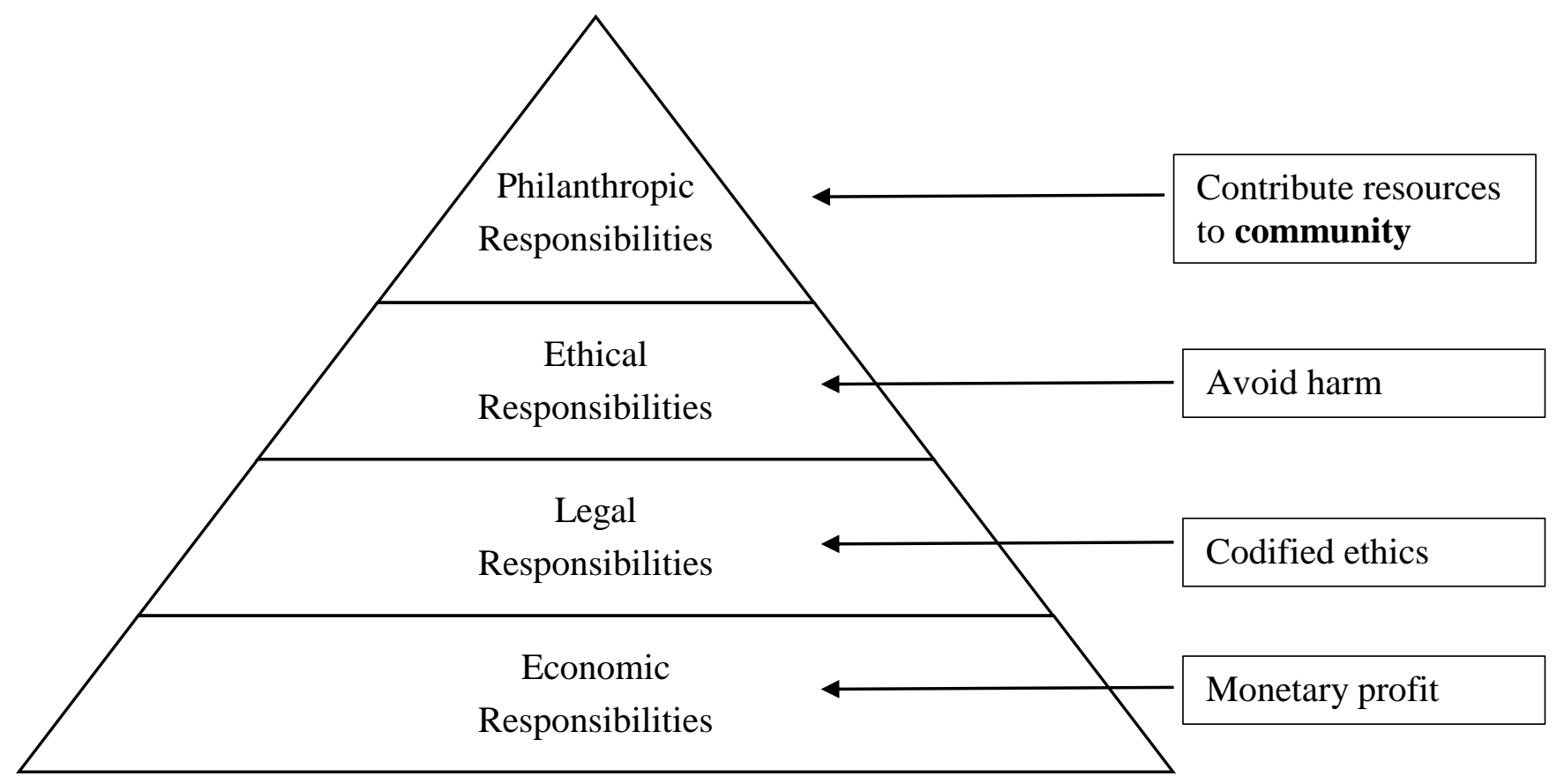




\section{Figure 2. Discontinuity in Index Weights Around Russell Indexes Threshold}

This figure plots the index weighs of the Russell indexes around the Russell threshold from 2007 to 2013. The $x$-axis represents the distance from the Russell indexes thresholds using the actual Russell ranks, where the zero is for the smallest firm in the Russell 1000.

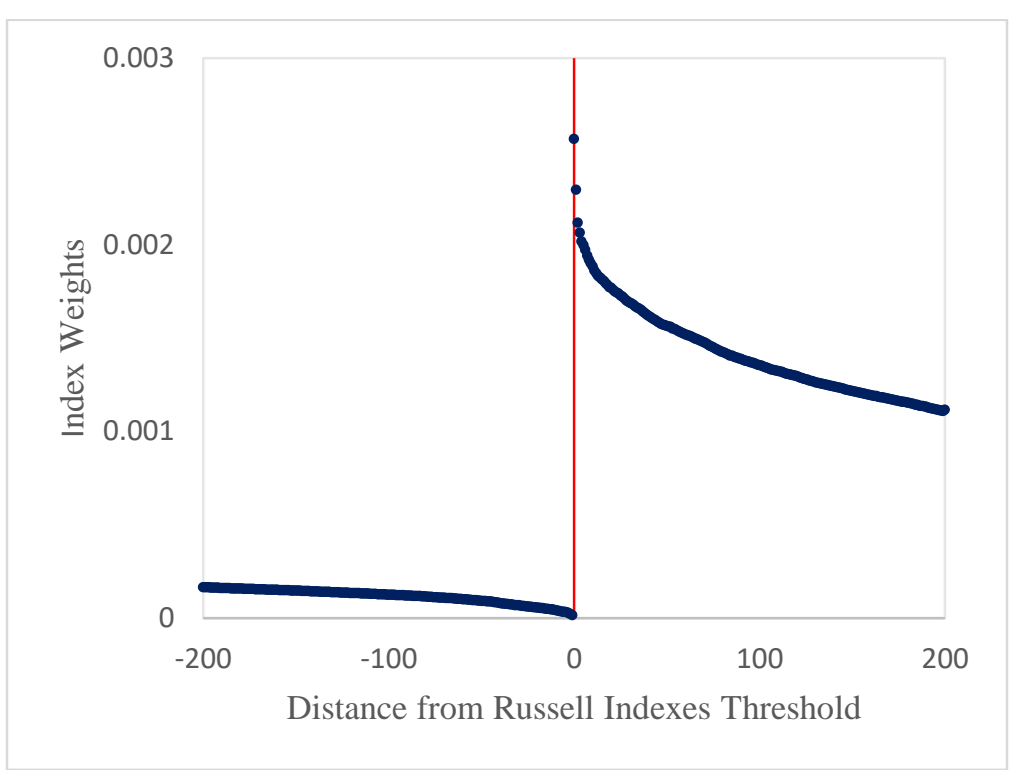


Table 1. Descriptive Statistics

\begin{tabular}{|c|c|c|c|c|c|}
\hline Variables & Mean & Q1 & Median & Q3 & $\mathrm{SD}$ \\
\hline \multicolumn{6}{|l|}{ Local Variables } \\
\hline Local & 0.0124 & 0.0000 & 0.0001 & 0.0106 & 0.0262 \\
\hline Local/Total & 0.0158 & 0.0000 & 0.0001 & 0.0145 & 0.0330 \\
\hline \multicolumn{6}{|l|}{ CSR Variables } \\
\hline CSR & -0.3513 & -2.0000 & -1.0000 & 1.0000 & 2.5718 \\
\hline CCR & 0.0812 & 0.0000 & 0.0000 & 0.0000 & 0.4928 \\
\hline \multicolumn{6}{|l|}{ Firm Characteristics } \\
\hline Size (in millions) & $8,471.1100$ & 484.8560 & $1,315.0300$ & $4,213.1200$ & $46,774.52$ \\
\hline $\mathrm{BM}$ & 0.5299 & 0.2734 & 0.4522 & 0.7017 & 0.3998 \\
\hline Tobin's Q & 1.3659 & 0.5792 & 1.0084 & 1.7360 & 1.2001 \\
\hline $\mathrm{OCF}$ & 0.0949 & 0.0535 & 0.0956 & 0.1444 & 0.0937 \\
\hline ROA & 0.0351 & 0.0147 & 0.0472 & 0.0847 & 0.1106 \\
\hline$|\mathrm{DACC}|$ & 0.1013 & 0.0275 & 0.0635 & 0.1279 & 0.1299 \\
\hline Leverage & 0.2232 & 0.0362 & 0.1923 & 0.3375 & 0.2080 \\
\hline CAPEX & 0.0856 & 0.0185 & 0.0343 & 0.0675 & 0.1762 \\
\hline Liquidity & 14.4855 & 14.0493 & 14.5200 & 14.9720 & 0.7230 \\
\hline Competition & -0.0793 & -0.0835 & -0.0623 & -0.0466 & 0.0562 \\
\hline Litigation & 0.2235 & 0.0000 & 0.0000 & 0.0000 & 0.4166 \\
\hline Fin & -0.0016 & -0.0402 & -0.0026 & 0.0166 & 0.1000 \\
\hline Global & 0.5817 & 0.0000 & 1.0000 & 1.0000 & 0.4933 \\
\hline IO & 0.7503 & 0.6326 & 0.8002 & 0.9117 & 0.2321 \\
\hline Number of observations & 8,361 & & & & \\
\hline
\end{tabular}

This table reports descriptive statistics. Local and Local/Total are measured as the sum of local mutual fund ownership and the sum of local mutual fund ownership over total institutional ownership, respectively. CSR and CCR are reported before standardization. All other variables are defined in the appendix. 
Table 2. The Effects of Local Shareholders on CSR and CCR

Panel A. All Industries

\begin{tabular}{|c|c|c|c|c|}
\hline Variable & $\stackrel{(1)}{\text { STDCSR }_{t}}$ & $\stackrel{(2)}{\text { STDCCR }_{t}}$ & $\stackrel{(3)}{\text { STDCSR }_{t}}$ & $\stackrel{(4)}{\text { STDCCR }_{t}}$ \\
\hline Local $_{t-1}$ & $\begin{array}{c}-0.1014 \\
(-0.25)\end{array}$ & $\begin{array}{c}1.3479 \\
(3.58)^{* * *}\end{array}$ & & \\
\hline Local/Total $_{\mathrm{t}-1}$ & & & $\begin{array}{c}0.2638 \\
(0.83)\end{array}$ & $\begin{array}{c}1.0516 \\
(3.59) * * *\end{array}$ \\
\hline $\log \left(\right.$ Size $\left._{t-1}\right)$ & $\begin{array}{c}0.2174 \\
(27.01)^{* * *}\end{array}$ & $\begin{array}{c}0.1956 \\
(26.47)^{* * *}\end{array}$ & $\begin{array}{c}0.2175 \\
(27.02)^{* * *}\end{array}$ & $\begin{array}{c}0.1956 \\
(26.52)^{* * *}\end{array}$ \\
\hline $\mathrm{BM}_{\mathrm{t}-1}$ & $\begin{array}{c}-0.2308 \\
(-8.92)^{* * *}\end{array}$ & $\begin{array}{c}-0.1426 \\
(-6.01)^{* * *}\end{array}$ & $\begin{array}{c}-0.2301 \\
(-8.90)^{* * *}\end{array}$ & $\begin{array}{c}-0.1413 \\
(-5.95)^{* * *}\end{array}$ \\
\hline Leverage $_{t-1}$ & $\begin{array}{c}-0.3212 \\
(-5.22)^{* * *}\end{array}$ & $\begin{array}{c}-0.2174 \\
(-3.85)^{* * *}\end{array}$ & $\begin{array}{c}-0.3209 \\
(-5.22)^{* * *}\end{array}$ & $\begin{array}{c}-0.2158 \\
(-3.82)^{* * * *}\end{array}$ \\
\hline $\mathrm{ROA}_{\mathrm{t}-1}$ & $\begin{array}{l}0.1884 \\
(1.87)^{*}\end{array}$ & $\begin{array}{c}-0.0580 \\
(-0.63)\end{array}$ & $\begin{array}{l}0.1877 \\
(1.86)^{*}\end{array}$ & $\begin{array}{c}-0.0611 \\
(-0.66)\end{array}$ \\
\hline$|\mathrm{DACC}|_{\mathrm{t}-1}$ & $\begin{array}{l}0.1815 \\
(1.71)^{*}\end{array}$ & $\begin{array}{c}0.0656 \\
(0.67)\end{array}$ & $\begin{array}{l}0.1821 \\
(1.71)^{*}\end{array}$ & $\begin{array}{c}0.0670 \\
(0.69)\end{array}$ \\
\hline CAPEX $_{\mathrm{t}-1}$ & $\begin{array}{l}0.1408 \\
(1.68)^{*}\end{array}$ & $\begin{array}{c}-0.1077 \\
(-1.40)\end{array}$ & $\begin{array}{l}0.1415 \\
(1.69)^{*}\end{array}$ & $\begin{array}{c}-0.1053 \\
(-1.37)\end{array}$ \\
\hline Liquidity $_{\mathrm{t}-1}$ & $\begin{array}{c}-0.0497 \\
(-2.77)^{* * *}\end{array}$ & $\begin{array}{c}-0.0686 \\
(-4.16)^{* * *}\end{array}$ & $\begin{array}{c}-0.0498 \\
(-2.77)^{* * *}\end{array}$ & $\begin{array}{c}-0.0676 \\
(-4.09)^{* * *}\end{array}$ \\
\hline Competition $_{\mathrm{t}-1}$ & $\begin{array}{l}1.5399 \\
(1.95)^{* *}\end{array}$ & $\begin{array}{c}2.3778 \\
(3.27)^{* * *}\end{array}$ & $\begin{array}{l}1.5270 \\
(1.93)^{* *}\end{array}$ & $\begin{array}{c}2.3836 \\
(3.28) * * *\end{array}$ \\
\hline Litigation $_{t-1}$ & $\begin{array}{c}0.3785 \\
(8.47)^{* * *}\end{array}$ & $\begin{array}{c}0.3203 \\
(7.81)^{* * *}\end{array}$ & $\begin{array}{c}0.3790 \\
(8.48)^{* * *}\end{array}$ & $\begin{array}{c}0.3210 \\
(7.83)^{* * * *}\end{array}$ \\
\hline $\mathrm{FIN}_{\mathrm{t}-1}$ & $\begin{array}{c}-0.3391 \\
(-2.97)^{* * *}\end{array}$ & $\begin{array}{c}-0.2599 \\
(-2.48) * * *\end{array}$ & $\begin{array}{c}-0.3364 \\
(-2.95)^{* * *}\end{array}$ & $\begin{array}{c}-0.2637 \\
(-2.52) * * *\end{array}$ \\
\hline Global $_{t-1}$ & $\begin{array}{l}-0.0523 \\
(-1.95)^{* *}\end{array}$ & $\begin{array}{l}-0.0527 \\
(-2.14)^{* *}\end{array}$ & $\begin{array}{l}-0.0539 \\
(-2.01)^{* *}\end{array}$ & $\begin{array}{l}-0.0531 \\
(-2.16)^{* *}\end{array}$ \\
\hline $\mathrm{IO}_{\mathrm{t}-1}$ & $\begin{array}{c}-0.2774 \\
(-5.38) * * *\end{array}$ & $\begin{array}{c}-0.1400 \\
(-2.96) * * *\end{array}$ & $\begin{array}{c}-0.2820 \\
(-5.51)^{* * *}\end{array}$ & $\begin{array}{c}-0.1285 \\
(-2.74)^{* * *}\end{array}$ \\
\hline Cons & $\begin{array}{c}-0.3370 \\
(-0.80)\end{array}$ & $\begin{array}{r}0.4803 \\
(1.24)\end{array}$ & $\begin{array}{c}-0.3432 \\
(-0.81)\end{array}$ & $\begin{array}{c}0.4455 \\
(1.15) \\
\end{array}$ \\
\hline $\begin{array}{l}\text { Year Fixed Effects } \\
\text { Industry Fixed }\end{array}$ & Yes & Yes & Yes & Yes \\
\hline Effects & Yes & Yes & Yes & Yes \\
\hline $\begin{array}{l}\text { Number of } \\
\text { observations } \\
\text { Adjusted } \mathrm{R}^{2}\end{array}$ & $\begin{array}{c}8,631 \\
0.1620 \\
\end{array}$ & $\begin{array}{c}8,631 \\
0.1326 \\
\end{array}$ & 0.1621 & $\begin{array}{c}8,631 \\
0.1326 \\
\end{array}$ \\
\hline
\end{tabular}


Panel B. Consumer Oriented Industries

\begin{tabular}{|c|c|c|c|c|}
\hline Variable & $\stackrel{(1)}{\text { STDCSR }_{t}}$ & $\stackrel{(2)}{\text { STDCCR }_{t}}$ & $\frac{(3)}{\text { STDCSR }_{t}}$ & $\stackrel{(4)}{\text { STDCCR }_{t}}$ \\
\hline Local $_{t-1}$ & $\begin{array}{c}-0.4367 \\
(-0.86)\end{array}$ & $\begin{array}{c}2.4348 \\
(5.26)^{* * *}\end{array}$ & & \\
\hline${\text { Local} / T_{\text {Tatal }}}_{\mathrm{t}-1}$ & & & $\begin{array}{c}-0.2189 \\
(-0.53)\end{array}$ & $\begin{array}{c}2.0344 \\
(5.46)^{* * *}\end{array}$ \\
\hline $\log \left(\right.$ Size $\left._{t-1}\right)$ & $\begin{array}{c}0.2444 \\
(21.25)^{* * *}\end{array}$ & $\begin{array}{c}0.2222 \\
(21.25)^{* * *}\end{array}$ & $\begin{array}{c}0.2443 \\
(21.23)^{* * *}\end{array}$ & $\begin{array}{c}0.2232 \\
(21.35)^{* * *}\end{array}$ \\
\hline $\mathrm{BM}_{\mathrm{t}-1}$ & $\begin{array}{l}-0.2515 \\
(-6.68) * * *\end{array}$ & $\begin{array}{c}-0.1445 \\
(-4.22) * * *\end{array}$ & $\begin{array}{c}-0.2511 \\
(-6.67) * * *\end{array}$ & $\begin{array}{c}-0.1435 \\
(-4.19) * * *\end{array}$ \\
\hline Leverage $_{t-1}$ & $\begin{array}{c}-0.5492 \\
(-6.66)^{* * *}\end{array}$ & $\begin{array}{c}-0.3515 \\
(-4.69)^{* * *}\end{array}$ & $\begin{array}{c}-0.5490 \\
(-6.66)^{* * * *}\end{array}$ & $\begin{array}{c}-0.3483 \\
(-4.65)^{* * * *}\end{array}$ \\
\hline $\mathrm{ROA}_{\mathrm{t}-1}$ & $\begin{array}{l}0.2701 \\
(1.96)^{* *}\end{array}$ & $\begin{array}{c}-0.1479 \\
(-1.18)\end{array}$ & $\begin{array}{c}0.2707 \\
(1.97)^{* *}\end{array}$ & $\begin{array}{c}-0.1409 \\
(1.13)\end{array}$ \\
\hline$|\mathrm{DACC}|_{\mathrm{t}-1}$ & $\begin{array}{c}0.4334 \\
(2.72)^{* * *}\end{array}$ & $\begin{array}{c}0.3322 \\
(2.29)^{* *}\end{array}$ & $\begin{array}{c}0.4334 \\
(2.72)^{* * *}\end{array}$ & $\begin{array}{c}0.3440 \\
(2.37)^{* *}\end{array}$ \\
\hline CAPEX $_{\mathrm{t}-1}$ & $\begin{array}{c}0.0753 \\
(0.50)\end{array}$ & $\begin{array}{c}-0.1300 \\
(-0.94)\end{array}$ & $\begin{array}{c}0.0749 \\
(0.49)\end{array}$ & $\begin{array}{c}-0.1289 \\
(-0.94)\end{array}$ \\
\hline Liquidity $_{\mathrm{t}-1}$ & $\begin{array}{l}-0.0535 \\
(-2.10)^{* *}\end{array}$ & $\begin{array}{c}-0.0375 \\
(-1.62)\end{array}$ & $\begin{array}{l}-0.0538 \\
(-2.12)^{* *}\end{array}$ & $\begin{array}{c}-0.0346 \\
(-1.50)\end{array}$ \\
\hline Competition $_{\mathrm{t}-1}$ & $\begin{array}{c}0.7303 \\
(0.63)\end{array}$ & $\begin{array}{l}1.4278 \\
(1.35)\end{array}$ & $\begin{array}{c}0.7218 \\
(0.62)\end{array}$ & $\begin{array}{l}1.4135 \\
(1.34)\end{array}$ \\
\hline Litigation $_{t-1}$ & $\begin{array}{c}0.0021 \\
(0.03)\end{array}$ & $\begin{array}{c}0.1795 \\
(2.97) * * *\end{array}$ & $\begin{array}{c}0.0020 \\
(0.03)\end{array}$ & $\begin{array}{c}0.1861 \\
(3.08)^{* * *}\end{array}$ \\
\hline $\mathrm{FIN}_{\mathrm{t}-1}$ & $\begin{array}{c}-0.2170 \\
(-1.43)\end{array}$ & $\begin{array}{c}-0.1348 \\
(-0.97)\end{array}$ & $\begin{array}{r}-0.2157 \\
(-1.42)\end{array}$ & $\begin{array}{c}-0.1394 \\
(-1.01)\end{array}$ \\
\hline Global $_{\mathrm{t}-1}$ & $\begin{array}{c}-0.0357 \\
(-1.01)\end{array}$ & $\begin{array}{l}-0.0388 \\
(-1.21)^{* *}\end{array}$ & $\begin{array}{c}-0.0363 \\
(-1.02)\end{array}$ & $\begin{array}{c}-0.0423 \\
(-1.31)\end{array}$ \\
\hline $\mathrm{IO}_{\mathrm{t}-1}$ & $\begin{array}{c}-0.2492 \\
(-3.40)^{* * *}\end{array}$ & $\begin{array}{c}-0.2699 \\
(-4.05)^{* * * *}\end{array}$ & $\begin{array}{c}-0.2550 \\
(-3.50) * * *\end{array}$ & $\begin{array}{c}-0.2505 \\
(-3.79) * * *\end{array}$ \\
\hline Cons & $\begin{array}{c}-0.6349 \\
(-1.17)\end{array}$ & $\begin{array}{c}-0.3420 \\
(-0.69)\end{array}$ & $\begin{array}{c}-0.6264 \\
(-1.15)\end{array}$ & $\begin{array}{c}-0.4272 \\
(0.86)\end{array}$ \\
\hline $\begin{array}{l}\text { Year Fixed Effects } \\
\text { Industry Fixed }\end{array}$ & Yes & Yes & Yes & Yes \\
\hline Effects & Yes & Yes & Yes & Yes \\
\hline $\begin{array}{l}\text { Number of } \\
\text { observations } \\
\text { Adjusted } \mathrm{R}^{2}\end{array}$ & $\begin{array}{c}4,347 \\
0.2036\end{array}$ & $\begin{array}{c}4,347 \\
0.2085\end{array}$ & 4,347 & $\begin{array}{c}4,347 \\
0.2089\end{array}$ \\
\hline
\end{tabular}

This table reports the multivariate regressions of CSR and CCR on local shareholders. Local is measured as the sum of local mutual fund ownership, and Local/Total is measured as the sum of local mutual fund ownership over total institutional ownership. Control variables are defined in Appendix. All regressions control for year and industry fixed effects. Consumer-oriented industry is classified based on Fama-French 48 industry and detailed industry classification is described in the main manuscript. ***, **, and * denote significance levels of $1 \%, 5 \%$, and $10 \%$, respectively. 
Table 3. The Effects of Corporate Community Responsibility on Firm Performance

Panel A. All Industries

\begin{tabular}{|c|c|c|c|c|}
\hline Variable & $\frac{(1)}{\text { Tobin's } Q_{t}}$ & $\frac{(2)}{\mathrm{OCF}_{\mathrm{t}}}$ & $\frac{(3)}{\text { Tobin's } Q_{t}}$ & $\frac{(4)}{\mathrm{OCF}_{\mathrm{t}}}$ \\
\hline STDCSR $_{\mathrm{t}-1}$ & $\begin{array}{c}0.0796 \\
(7.35)^{* * *}\end{array}$ & $\begin{array}{c}0.0035 \\
(3.66) * * *\end{array}$ & & \\
\hline $\mathrm{STDCCR}_{\mathrm{t}-1}$ & & & $\begin{array}{c}0.0685 \\
(5.88)^{* * *}\end{array}$ & $\begin{array}{l}0.0021 \\
(2.03)^{* *}\end{array}$ \\
\hline $\log \left(\right.$ Size $\left._{t-1}\right)$ & $\begin{array}{c}-0.1384 \\
(-16.53)^{* * *}\end{array}$ & $\begin{array}{c}0.0057 \\
(7.55)^{* * *}\end{array}$ & $\begin{array}{c}-0.1332 \\
(-16.02)^{* * *}\end{array}$ & $\begin{array}{c}0.0061 \\
(8.19)^{* * *}\end{array}$ \\
\hline $\mathrm{BM}_{\mathrm{t}-1}$ & $\begin{array}{c}-1.1045 \\
(-41.70)^{* * *}\end{array}$ & $\begin{array}{c}-0.0420 \\
(-17.72)^{* * *}\end{array}$ & $\begin{array}{c}-1.1140 \\
(-42.13)^{* * *}\end{array}$ & $\begin{array}{c}-0.0425 \\
(-18.00)^{* * *}\end{array}$ \\
\hline Leverage $_{t-1}$ & $\begin{array}{c}-1.5914 \\
(-25.75)^{* * *}\end{array}$ & $\begin{array}{c}-0.0498 \\
(-9.00)^{* * *}\end{array}$ & $\begin{array}{c}-1.5990 \\
(-25.86)^{* * *}\end{array}$ & $\begin{array}{c}-0.0504 \\
(-9.12)^{* * *}\end{array}$ \\
\hline$|\mathrm{DACC}|_{\mathrm{t}-1}$ & $\begin{array}{c}1.4411 \\
(13.21)^{* * *}\end{array}$ & $\begin{array}{c}0.0935 \\
(9.59)^{* * *}\end{array}$ & $\begin{array}{c}1.4657 \\
(13.43)^{* * *}\end{array}$ & $\begin{array}{c}0.0947 \\
(9.71)^{* * *}\end{array}$ \\
\hline CAPEX $_{\mathrm{t}-1}$ & $\begin{array}{c}0.2186 \\
(2.53)^{* *}\end{array}$ & $\begin{array}{c}0.0294 \\
(3.80)^{* * *}\end{array}$ & $\begin{array}{c}0.2317 \\
(2.68)^{* * *}\end{array}$ & $\begin{array}{c}0.0299 \\
(3.88)^{* * *}\end{array}$ \\
\hline Liquidity $_{\mathrm{t}-1}$ & $\begin{array}{c}0.1934 \\
(10.51)^{* * *}\end{array}$ & $\begin{array}{c}-0.0065 \\
(-3.92)^{* * *}\end{array}$ & $\begin{array}{c}0.1943 \\
(10.55)^{* * *}\end{array}$ & $\begin{array}{c}-0.0065 \\
(-3.92)^{* * *}\end{array}$ \\
\hline Competition $_{\mathrm{t}-1}$ & $\begin{array}{c}-0.9012 \\
(-1.02)\end{array}$ & $\begin{array}{c}-0.0099 \\
(-0.13)\end{array}$ & $\begin{array}{c}-0.9388 \\
(-1.06)\end{array}$ & $\begin{array}{c}-0.0088 \\
(-0.11)\end{array}$ \\
\hline Litigation $_{t-1}$ & $\begin{array}{c}0.4380 \\
(9.70)^{* * *}\end{array}$ & $\begin{array}{c}-0.0174 \\
(-4.31)^{* * *}\end{array}$ & $\begin{array}{c}0.4457 \\
(9.87)^{* * *}\end{array}$ & $\begin{array}{c}-0.0167 \\
(-4.15) * * *\end{array}$ \\
\hline $\mathrm{FIN}_{\mathrm{t}-1}$ & $\begin{array}{c}0.8434 \\
(7.36)^{* * *}\end{array}$ & $\begin{array}{c}-0.1981 \\
(-19.32)^{* * *}\end{array}$ & $\begin{array}{c}0.8311 \\
(7.24)^{* * *}\end{array}$ & $\begin{array}{c}-0.1989 \\
(-19.40)^{* * *}\end{array}$ \\
\hline Global $_{t-1}$ & $\begin{array}{c}-0.0718 \\
(-2.66)^{* * *}\end{array}$ & $\begin{array}{c}-0.0025 \\
(-1.05)\end{array}$ & $\begin{array}{c}-0.0728 \\
(-2.70)^{* * *}\end{array}$ & $\begin{array}{c}-0.0026 \\
(-1.08)\end{array}$ \\
\hline $\mathrm{IO}_{\mathrm{t}-1}$ & $\begin{array}{r}0.0237 \\
(0.45)\end{array}$ & $\begin{array}{c}0.0593 \\
(12.46)^{* * *}\end{array}$ & $\begin{array}{l}0.0086 \\
(0.16)\end{array}$ & $\begin{array}{c}0.0584 \\
(12.30)^{* * *}\end{array}$ \\
\hline Cons & $\begin{array}{c}0.2768 \\
(0.65) \\
\end{array}$ & $\begin{array}{c}0.0861 \\
(2.25)^{* *} \\
\end{array}$ & $\begin{array}{c}0.2768 \\
(0.65) \\
\end{array}$ & $\begin{array}{c}0.0831 \\
(2.17)^{* *} \\
\end{array}$ \\
\hline $\begin{array}{l}\text { Year Fixed Effects } \\
\text { Industry Fixed }\end{array}$ & Yes & Yes & Yes & Yes \\
\hline Effects & Yes & Yes & Yes & Yes \\
\hline $\begin{array}{l}\text { Number of } \\
\text { observations } \\
\text { Adjusted R }\end{array}$ & $\begin{array}{c}7,414 \\
0.4419 \\
\end{array}$ & $\begin{array}{c}7,414 \\
0.2419 \\
\end{array}$ & 7,414 & $\begin{array}{c}7,414 \\
0.2410 \\
\end{array}$ \\
\hline
\end{tabular}


Panel B. Consumer Oriented Industries

\begin{tabular}{|c|c|c|c|c|}
\hline Variable & $\stackrel{(1)}{\text { Tobin's } Q_{t}}$ & $\frac{(2)}{\mathrm{OCF}_{\mathrm{t}}}$ & $\frac{(3)}{\text { Tobin's } Q_{t}}$ & $\frac{(4)}{\mathrm{OCF}_{\mathrm{t}}}$ \\
\hline STDCSR $_{\mathrm{t}-1}$ & $\begin{array}{c}0.1042 \\
(6.24) * * *\end{array}$ & $\begin{array}{c}0.0041 \\
(2.84)^{* * *}\end{array}$ & & \\
\hline $\operatorname{STDCCR}_{\mathrm{t}-1}$ & & & $\begin{array}{c}0.0888 \\
(4.88) * * *\end{array}$ & $\begin{array}{c}0.0041 \\
(2.61)^{* * *}\end{array}$ \\
\hline $\log \left(\right.$ Size $\left._{t-1}\right)$ & $\begin{array}{c}-0.1163 \\
(-8.87)^{* * *}\end{array}$ & $\begin{array}{c}0.0101 \\
(8.85)^{* * *}\end{array}$ & $\begin{array}{c}-0.1092 \\
(-8.36) * * *\end{array}$ & $\begin{array}{c}0.0103 \\
(9.02)^{* * *}\end{array}$ \\
\hline $\mathrm{BM}_{\mathrm{t}-1}$ & $\begin{array}{c}-1.2269 \\
(-29.22) * * *\end{array}$ & $\begin{array}{c}-0.0343 \\
(-9.35)^{* * *}\end{array}$ & $\begin{array}{c}-1.2386 \\
(-29.51)^{* * *}\end{array}$ & $\begin{array}{c}-0.0347 \\
(-9.47)^{* * *}\end{array}$ \\
\hline Leverage $_{t-1}$ & $\begin{array}{c}-1.2269 \\
(-19.05)^{* * *}\end{array}$ & $\begin{array}{c}-0.0526 \\
(-6.59)^{* * *}\end{array}$ & $\begin{array}{c}-1.7591 \\
(-19.27)^{* * *}\end{array}$ & $\begin{array}{c}-0.0532 \\
(-6.67)^{* * *}\end{array}$ \\
\hline$|\mathrm{DACC}|_{\mathrm{t}-1}$ & $\begin{array}{c}1.8855 \\
(10.77)^{* * *}\end{array}$ & $\begin{array}{c}0.0647 \\
(9.59)^{* * *}\end{array}$ & $\begin{array}{c}1.9114 \\
(10.90)^{* * *}\end{array}$ & $\begin{array}{c}0.0655 \\
(4.28) * * *\end{array}$ \\
\hline CAPEX $_{\mathrm{t}-1}$ & $\begin{array}{c}-0.0252 \\
(-0.14)\end{array}$ & $\begin{array}{l}0.0154 \\
(-0.98)\end{array}$ & $\begin{array}{c}-0.0058 \\
(-0.03)\end{array}$ & $\begin{array}{l}0.0145 \\
(-0.93)\end{array}$ \\
\hline Liquidity $_{t-1}$ & $\begin{array}{c}0.1895 \\
(6.69) * * *\end{array}$ & $\begin{array}{c}-0.0166 \\
(-6.70)^{* * *}\end{array}$ & $\begin{array}{c}0.1878 \\
(6.62) * * *\end{array}$ & $\begin{array}{c}-0.0167 \\
(-6.73) * * *\end{array}$ \\
\hline Competition $_{\mathrm{t}-1}$ & $\begin{array}{c}-1.4372 \\
(-0.99)\end{array}$ & $\begin{array}{c}-0.0819 \\
(-0.65)\end{array}$ & $\begin{array}{c}-1.5232 \\
(-1.05)\end{array}$ & $\begin{array}{c}-0.0864 \\
(-0.68)\end{array}$ \\
\hline Litigation $_{\mathrm{t}-1}$ & $\begin{array}{c}0.4245 \\
(5.77)^{* * *}\end{array}$ & $\begin{array}{c}-0.0073 \\
(-1.14)\end{array}$ & $\begin{array}{c}0.4126 \\
(5.59) * * *\end{array}$ & $\begin{array}{c}-0.0079 \\
(-1.23)\end{array}$ \\
\hline $\mathrm{FIN}_{\mathrm{t}-1}$ & $\begin{array}{l}1.0650 \\
(6.48)^{* * *}\end{array}$ & $\begin{array}{c}-0.2348 \\
(-16.32)^{* * *}\end{array}$ & $\begin{array}{c}1.0501 \\
(5.59) * * *\end{array}$ & $\begin{array}{c}-0.2352 \\
(-16.35)^{* * *}\end{array}$ \\
\hline Global $_{t-1}$ & $\begin{array}{c}-0.0364 \\
(-0.94)\end{array}$ & $\begin{array}{c}0.0021 \\
(0.61)\end{array}$ & $\begin{array}{c}-0.0372 \\
(-0.96)\end{array}$ & $\begin{array}{c}0.0021 \\
(0.61)\end{array}$ \\
\hline $\mathrm{IO}_{\mathrm{t}-1}$ & $\begin{array}{c}0.0489 \\
(0.60)\end{array}$ & $\begin{array}{c}0.0790 \\
(11.15)^{* * *}\end{array}$ & $\begin{array}{c}-0.0379 \\
(-0.96)\end{array}$ & $\begin{array}{c}0.0787 \\
(11.12)^{* * *}\end{array}$ \\
\hline Cons & $\begin{array}{l}0.1980 \\
(0.32)\end{array}$ & $\begin{array}{c}0.1661 \\
(3.11)^{* * *}\end{array}$ & $\begin{array}{l}0.0377 \\
(0.46)\end{array}$ & $\begin{array}{c}0.1641 \\
(3.07)^{* * *}\end{array}$ \\
\hline $\begin{array}{l}\text { Year Fixed Effects } \\
\text { Industry Fixed }\end{array}$ & Yes & Yes & Yes & Yes \\
\hline Effects & Yes & Yes & Yes & Yes \\
\hline $\begin{array}{l}\text { Number of } \\
\text { observations } \\
\text { Adjusted } \mathrm{R}^{2}\end{array}$ & $\begin{array}{c}3,717 \\
0.4438\end{array}$ & $\begin{array}{c}3,717 \\
0.2866\end{array}$ & $\begin{array}{c}3,717 \\
0.4415\end{array}$ & $\begin{array}{c}3,717 \\
0.2863\end{array}$ \\
\hline
\end{tabular}

This table reports the multivariate regressions of firm performance measures on CCR. Control variables are defined in Appendix. All regressions control for year and industry fixed effects. The number of observation in Panel A and B are 7,414 and 3,717 respectively due to missing lag CSR and CCR variables observed. Consumer oriented industry is classified based on Fama-French 48 industry and detailed industry classification is described in the main manuscript. $* * *, * *$, and $*$ denote significance levels of $1 \%, 5 \%$, and $10 \%$, respectively. 
Table 4. The Effects of Corporate Community Responsibility on Fund Flows

\begin{tabular}{ccccc} 
Variable & (1) Fund Flows & $\begin{array}{c}\text { (2) Scaled Fund } \\
\text { Flows }\end{array}$ & (3) Fund Flows & $\begin{array}{c}\text { (4) Scaled Fund } \\
\text { Flows }\end{array}$ \\
\hline STDCCR $_{\mathrm{t}-1}$ & $6.4688^{* * *}$ & $0.5039^{* *}$ & $3.0076^{* *}$ & $0.3803^{*}$ \\
& $(5.21)$ & $(2.38)$ & $(2.53)$ & $(1.79)$ \\
\hline Fund Controls & No & No & Yes & Yes \\
Year Fixed & Yes & Yes & Yes & Yes \\
Effects & 0.0139 & 0.0124 & 0.1258 & 0.0277 \\
Adj R-sq. & 8,631 & 8,631 & 8,631 & 8,631 \\
OBS. & &
\end{tabular}

This table reports regressions of mutual fund flows on CCR. All regressions control for year fixed effects. Fund Flows is the sum of local mutual funds' annual fund flows, and Scaled Fund Flows is Fund Flows scaled by the total number of local mutual funds holding a sample firm. ***,**, and * denote significance levels of $1 \%, 5 \%$, and $10 \%$, respectively 
Table 5. Causality Tests Using Russell Indexes Thresholds

\begin{tabular}{|c|c|c|c|c|}
\hline & First Stage & Second Stage & First Stage & Second Stage \\
\hline Variable & (1) Local & (2) STDCCR & Locall/Total & (4) STDCCR \\
\hline Russell2000 & $\begin{array}{c}2.8734 * * \\
(2.35)\end{array}$ & & $\begin{array}{c}3.8128 * * \\
(2.52)\end{array}$ & \\
\hline$\widehat{\text { Local }}$ & & $\begin{array}{c}0.1763 * \\
(1.81)\end{array}$ & & \\
\hline Local/Total & & & & $\begin{array}{c}0.1242 * \\
(1.68)\end{array}$ \\
\hline Banding Control & Yes & Yes & Yes & Yes \\
\hline Float Control & Yes & Yes & Yes & Yes \\
\hline Control Variables & Yes & Yes & Yes & Yes \\
\hline Year Fixed Effects & Yes & Yes & Yes & Yes \\
\hline R-sq. & 0.0985 & 0.0451 & 0.1437 & 0.0511 \\
\hline OBS. & 323 & 323 & 323 & 323 \\
\hline
\end{tabular}

This table reports the two-stage regressions of CCR on local mutual fund ownership, with the addition to Russell 2000 as the instrumental variable. The first and second stages estimate the Eq. (3) and (4), respectively. The first stage estimates local ownership as a function of the Russell 2000 inclusion, and the second stage estimates CCR as a function of instrumented local ownership. Local is measured as the sum of local mutual fund ownership, and Local/Total is measured as the sum of local mutual fund ownership over total institutional ownership. All regressions control for year fixed effects. The results show estimates for a \pm 100 bandwidth around the thresholds. The t-statistics are reported in parentheses. ***, **, and * denote significance levels of $1 \%, 5 \%$, and $10 \%$, respectively. 